\title{
Attaching and effacing lesions caused by Escherichia coli 0157:H7 in experimentally inoculated neonatal lambs
}

\author{
ANDREW D. WALES, GEOFFREY R. PEARSON, ANDREW M. SKUSE, JOHN M. ROE*, \\ CHRISTINE M. HAYES*, ADRIAN L. COOKSONं and MARTIN J. WOODWARD†
}

Department of Pathology and Microbiology and * Department of Clinical Veterinary Science, University of Bristol Veterinary School, Langford, Bristol BS40 7DU and †Department of Bacterial Diseases, Veterinary Laboratories Agency (Weybridge), Woodham Lane, New Haw, Addlestone, Surrey KT15 3NB

\begin{abstract}
Four 6-day-old conventionally reared lambs were inoculated orally with a total of $10^{9} \mathrm{cfu}$ comprising equal numbers of four enterohaemorrhagic Escherichia coli (EHEC) O157:H7 strains. All animals remained clinically normal. Tissues were sampled under terminal anaesthesia at 12, 36, 60 and $84 \mathrm{~h}$ post inoculation (hpi). EHEC 0157:H7 was cultured from most gastrointestinal tract sites. Small, sparse attaching and effacing (AE) lesions were found in the caecum at 12 and $36 \mathrm{hpi}$ and in the terminal colon and rectum at $84 \mathrm{hpi}$. Organisms in the lesions were labelled specifically by an 0157 antiserum. The results indicate that the well-characterised mechanisms for intimate attachment encoded by the locus for enterocyte effacement (LEE) of EHEC 0157:H7 may contribute to the initial events, at least, of colonisation of sheep.
\end{abstract}

\section{Introduction}

Enterohaemorrhagic Escherichia coli (EHEC) serotype O157:H7 infection of man is potentially fatal in the very young and the elderly and major incidents worldwide, including the UK, have been well documented [1-3]. Diarrhoeal disease may be complicated by the haemolytic-uraemic syndrome, which is thought to be caused by the verotoxins (VT) produced by this pathogen [2].

Cattle are considered to be the primary reservoir for EHEC O157:H7 [4], but recent reports also point to sheep as a significant source [5-8]. The mechanism by which E. coli $\mathrm{O} 157: \mathrm{H} 7$ colonises cattle and sheep remains to be fully elucidated, but it may involve formation of attaching and effacing (AE) lesions. These lesions form in vitro on HEp-2 and HeLa cells, mediated by secreted and surface arrayed bacterial proteins that are chromosomally encoded within the locus for enterocyte effacement (LEE) pathogenicity island [9]. In vivo, $\mathrm{AE}$ lesions form in the ileum and

Received 13 Nov. 2000; revised version accepted 24 Feb. 2001.

Corresponding author: Professor M.J. Woodward (e-mail: M.J.Woodward@vla.defra.gov.uk). large intestine of gnotobiotic piglets and the intimin surface arrayed protein of E. coli $\mathrm{O} 157: \mathrm{H} 7$ encoded by the eaeA gene of the LEE is essential for this process $[10,11]$.

In colostrum-deprived (CD) and colostrum-fed (CF) neonatal calves inoculated with $10^{10} \mathrm{cfu}$ of either of two EHEC O157:H7 strains at $12-36 \mathrm{~h}$ of age, AE lesions developed in the ileum and large intestines [12]. Dean-Nystrom et al. [13] showed that the intimin encoded by the eaeA gene in several different EHEC O157:H7 strains was necessary for the formation of AE lesions in $\mathrm{CD}$ neonatal calves. In contrast, 5-day-old $\mathrm{CD}$ gnotobiotic calves inoculated orally with $10^{9} \mathrm{cfu}$ of a single EHEC O157:H7 strain remained clinically normal with no evidence of AE lesions [14]. Multifocal $\mathrm{AE}$ lesions were observed in the caecum and rectum in three of nine 4-month-old weaned calves inoculated with $10^{10} \mathrm{cfu}$ of an EHEC O157:H7 strain after a period of fasting [15]. Other reports suggest that experimental inoculation of weaned calves with EHEC O157:H7 produces transient mild diarrhoea or excessively mucoid faeces in a proportion of animals, with no histological or immunohistochemical evidence for mucosal adherence or pathological changes [16-18]. A transient, asymptomatic carrier status has been induced experimentally and observed naturally in older animals $[16,18,19]$. 
Little is known of the mechanisms by which EHEC O157:H7 colonises and persists in sheep, but carriage may be observed for up to 2 months [20], possibly influenced by diet [21]. The 6-month-old sheep inoculated with $10^{9} \mathrm{cfu}$ of the four-strain mixture of EHEC O157:H7 used in this study remained clinically normal without diarrhoea or evidence of AE lesions when examined over 2 weeks (22). The purpose of this study was to investigate whether E. coli O157:H7 forms AE lesions in conventionally reared neonatal sheep.

\section{Materials and methods}

\section{Animals and experimental procedures}

Four Merino-cross lambs were allowed to suckle immediately after parturition and received milk replacer by bottle over the ensuing 5 days. Each animal was inoculated orally with a four-strain mixture of $E$. coli O157:H7 administered by syringe at 6 days of age. Animals were observed at 4 -h intervals. Rectal temperatures were determined at the time of inoculation, 15-h post-inoculation (hpi) and at 24-h intervals thereafter.

Tissues were sampled under terminal anaesthesia from the lambs (designated A, B, C and D) at 12, 36, 60 and $84 \mathrm{hpi}$, respectively. On each occasion, the lamb was placed in left lateral recumbency and the right flank and inguinal area were soaked with a chlorhexidinebased surgical scrub. A U-shaped incision in the exposed flank, plus dissection of the pelvic cavity and submandibular tissues, permitted aseptic collection of samples from the rumen, duodenum, jejunum, ileum, caecum, ascending colon (two sites), terminal colon, rectum, mesenteric lymph nodes, liver, spleen and kidney, for histological and bacteriological examination. Clips and latex gloves were used to enclose the cut ends of the intestinal tract, to minimise crosscontamination of samples.

All procedures were performed under Home Office (UK) and local ethical review committee approval and complied with the Animals (Scientific Procedures) Act 1986.

\section{Bacteriological studies}

Bacterial strains and inocula. Two human (EC157 and 140065) and two bovine (218 and 222) EHEC O157:H7 strains were confirmed by PCR to possess the LEE genes eaeA and esp A, plus the pO157 virulence plasmid genes $h l y \mathrm{~A}$, esp $\mathrm{P}, k a t \mathrm{P}$ and etpD. Strains EC157 and 218 possessed both verotoxin 1 $($ stx 1$)$ and verotoxin 2 (stx2) genes, whereas strains 140065 and 222 possessed stx 2 only. Strains were differentially marked by plating on Luria Bertani (LB) agar plates containing either nalidixic acid $(15 \mathrm{mg} / \mathrm{L})$, rifampicin $(150 \mathrm{~g} / \mathrm{L})$ or streptomycin $(25 \mathrm{~g} / \mathrm{L})$ alone, or both nalidixic acid $(15 \mathrm{~g} / \mathrm{L})$ and rifampicin
$(150 \mathrm{~g} / \mathrm{L})$, to select for spontaneous antibiotic-resistant mutants. Resistant colonies (EC157 str ${ }^{r}, 140065$ $\mathrm{nal}^{r}, 218 \mathrm{rif}^{r}$ and $222 \mathrm{nal}^{r} / \mathrm{rif}^{r}$ ) were subcultured three further times on the same medium then maintained on Dorset egg medium at room temperature. Marked strains showed the same phenotype as their progenitor wild-type strains with regard to production of localised adherence on HEp-2 tissueculture cells, generation of actin re-arrangements as demonstrated by fluorescent actin staining under adherent cells [23], and rate of growth under laboratory conditions.

For the four-strain mixed inoculum, 2.5-ml volumes from overnight LB broth cultures of each of the four antibiotic-resistant strains were mixed together and made up to $100 \mathrm{ml}$ with phosphate-buffered saline (PBS, pH 7.4). This bacterial suspension contained approximately equal numbers of the four strains, totalling $10^{8} \mathrm{cfu} / \mathrm{ml} ; 10 \mathrm{ml}$ of this suspension was used as the oral inoculum.

Bacteriological examination. Before inoculation, rectal swabs were taken from all lambs at 4 days of age. They were also taken at $6 \mathrm{hpi}$ and $12 \mathrm{hpi}$. Thereafter, $c$. $1 \mathrm{~g}$ of faeces was obtained from lambs B, C and D at 36 hpi, lambs C and D at 60 hpi, and lamb D at 84 hpi. The faeces samples were either freshly voided or taken directly from the rectum. Rectal swabs were vortex mixed in $10 \mathrm{ml}$ of buffered peptone water (BPW) and faeces samples were vortex mixed in $9 \mathrm{ml}$ of BPW. Tissue samples $(2.5 \mathrm{~g})$ were homogenised in $22.5 \mathrm{ml}$ of BPW. Tissue samples were collected from the terminal colon and rectum, from which $c .1 \mathrm{~g}$ of luminal contents was removed and vortex mixed with $9 \mathrm{ml}$ of BPW.

To determine a semi-quantitative bacterial count from each sample, serial dilutions were made in BPW from each primary sample. Each dilution was incubated for $6 \mathrm{~h}$ at $37^{\circ} \mathrm{C}$, then $1 \mathrm{ml}$ was processed by immunomagnetic separation (IMS) [5]. IMS beads from each sample were plated on four separate Chromagar plates, each supplemented with the appropriate antibiotic(s) for strain differentiation. The serogroup of the bacteria recovered from these experiments was confirmed by O157-specific latex agglutination (Oxoid).

\section{Pathological studies}

Light microscopy. Tissues were placed, within $1 \mathrm{~min}$ of removal, in buffered formalin $10 \%$ and buffered glutaraldehyde $2.5 \%$ at room temperature and fixed for at least $24 \mathrm{~h}$. Trimmed tissues were processed routinely to paraffin wax, and $4-\mu \mathrm{m}$ sections were stained with haematoxylin and eosin (H\&E). Sections of large intestine (7-11 from each sampling site), ileum (5), jejunum (2), duodenum (2) and a single section of other tissues were examined. 
Electron microscopy. After examination of tissues by light microscopy, small pieces of the caecum of the lamb sampled at $36 \mathrm{hpi}$ (B) and the rectum of the lamb sampled at 84 hpi (D) were cut out of the paraffin wax blocks. The excised tissue was dewaxed, rehydrated, post-fixed in osmium tetroxide and embedded in epoxy resin. Thin sections were examined with a Philips 201 transmission electron microscope.

Immunohistochemistry. Briefly, sections were labelled with a primary polyclonal $\mathrm{O} 157$ ' $\mathrm{O}$ ' antiserum raised in a rabbit. A goat anti-rabbit bridge antibody, rabbit peroxidase-antiperoxidase complex and diaminobenzidine (DAB) were sequentially applied. The sections were counterstained with Mayer's haematoxylin.

Thin sections were prepared from the resin-embedded rectal tissue from lamb $\mathrm{D}$ for immunogold labelling. The sections were mounted on gold grids and incubated sequentially in normal goat serum 5\%, polyclonal rabbit $\mathrm{O} 157$ ' $\mathrm{O}$ ' antiserum diluted 1 in 5 in TBS, and 10-nm gold-conjugated goat anti-rabbit IgG (British Biocell International, Cardiff) diluted 1 in 50 in TBS. Bovine serum albumin was included in the antiserum diluents to reduce non-specific binding. The immuno- labelled sections were post-fixed in buffered glutaraldehyde $2.5 \%$ and counterstained with lead citrate and uranyl acetate.

\section{Results}

\section{Clinical findings}

The lambs remained normal throughout the experiment, with no evidence of pyrexia or diarrhoea.

\section{Bacteriological findings}

The lambs were confirmed to be free of E. coli $\mathrm{O} 157$ before inoculation, and the results following inoculation are shown in Tables 1 and 2.

E. coli $\mathrm{O} 157$ was isolated from all cultured samples of the gastrointestinal tract, with the exception of the rectum of lamb $B$. In all cases the highest numbers were recovered from the caecum and spiral colon. In lamb B, no E. coli $\mathrm{O} 157$ were recovered from samples taken from the rectum, whereas high numbers of all four differentially marked E. coli 0157 strains were recovered from terminal colon tissue and contents.

Table 1. Viable counts of E. coli O157:H7 recovered from rectal swabs and faeces of neonatal lambs inoculated orally at 6 days of age with a four-strain mixture of organisms

\begin{tabular}{|c|c|c|c|c|c|c|c|c|c|c|c|c|c|c|c|c|}
\hline \multirow[b]{3}{*}{ Sample time* } & \multicolumn{16}{|c|}{$\log _{10} \mathrm{cfu}^{\dagger}$ recovered from lambs } \\
\hline & \multicolumn{4}{|c|}{ A } & \multicolumn{4}{|c|}{$\mathrm{B}$} & \multicolumn{4}{|c|}{$\mathrm{C}$} & \multicolumn{4}{|c|}{$\mathrm{D}$} \\
\hline & $\mathrm{N}$ & $\mathrm{R}$ & $\mathrm{S}$ & NR & $\mathrm{N}$ & $\mathrm{R}$ & $\mathrm{S}$ & NR & $\mathrm{N}$ & $\mathrm{R}$ & $\mathrm{S}$ & NR & $\mathrm{N}$ & $\mathrm{R}$ & $\mathrm{S}$ & NR \\
\hline 6 hpi & - & - & - & - & 1 & 1 & - & 1 & 1 & 1 & - & 1 & 4 & 4 & 1 & 4 \\
\hline 12 hpi & - & - & - & - & - & - & - & - & 1 & 1 & - & - & $\geqslant 6$ & $\geqslant 6$ & 4 & $\geqslant 6$ \\
\hline 36 hpi & & & & & $\geqslant 6$ & $\geqslant 6$ & $\geqslant 6$ & $\geqslant 6$ & $\geqslant 6$ & $\geqslant 6$ & $\geqslant 6$ & $\geqslant 6$ & $\geqslant 6$ & $\geqslant 6$ & $\geqslant 6$ & $\geqslant 6$ \\
\hline 60 hpi & & & & & & & & & $\geqslant 6$ & $\geqslant 6$ & 2 & 4 & $\geqslant 6$ & $\geqslant 6$ & 4 & $\geqslant 6$ \\
\hline 84 hpi & & & & & & & & & & & & & $\geqslant 7$ & $\geqslant 7$ & $\geqslant 7$ & - \\
\hline
\end{tabular}

E. coli $\mathrm{O} 157: \mathrm{H} 7$ strains140065 nal $^{\mathrm{r}}(\mathrm{N}), 218$ rif $^{\mathrm{r}}(\mathrm{R}), \mathrm{EC} 157$ str $^{\mathrm{r}}(\mathrm{S})$ and 222 nal $^{\mathrm{r}}$ rif $^{\mathrm{r}}(\mathrm{NR})$ were recovered on selective media $($ see Materials and methods). ${ }^{*}$ Samples at 6 and 12 hours postinoculation (hpi) were rectal swabs, later samples comprised $1 \mathrm{~g}$ of faeces. ${ }^{\dagger}$ Limit of detection on faeces samples was $10 \mathrm{cfu} / \mathrm{g}$; -, organisms not detected.

Table 2. Viable counts of E. coli O157:H7 recovered from tissues of neonatal lambs inoculated orally at 6 days of age with a four-strain mixture of organisms

\begin{tabular}{|c|c|c|c|c|c|c|c|c|c|c|c|c|c|c|c|c|}
\hline \multirow[b]{3}{*}{ Sample } & \multicolumn{16}{|c|}{$\log _{10} \mathrm{cfu}^{\dagger}$ recovered from lambs } \\
\hline & \multicolumn{4}{|c|}{ A (12 hpi) } & \multicolumn{4}{|c|}{ B (36 hpi) } & \multicolumn{4}{|c|}{ C (60 hpi) } & \multicolumn{4}{|c|}{ D (84 hpi) } \\
\hline & $\mathrm{N}$ & $\mathrm{R}$ & $\mathrm{S}$ & NR & $\mathrm{N}$ & $\mathrm{R}$ & $\mathrm{S}$ & NR & $\mathrm{N}$ & $\mathrm{R}$ & $\mathrm{S}$ & NR & $\mathrm{N}$ & $\mathrm{R}$ & $\mathrm{S}$ & NR \\
\hline Mesenteric lymph nodes & - & - & - & - & - & - & - & - & $1^{\dagger}$ & $1^{\dagger}$ & $1^{\dagger}$ & $1^{\dagger}$ & - & - & - & - \\
\hline Tonsil & 2 & 2 & - & - & 2 & 2 & 2 & 2 & 2 & 2 & 2 & - & - & - & - & - \\
\hline Rumen & 2 & 4 & 2 & 2 & 2 & 2 & 2 & 2 & 2 & 2 & 2 & 2 & 4 & 1 & - & - \\
\hline Ileum & 4 & 4 & 2 & 4 & 4 & 4 & 2 & 2 & $\geqslant 6$ & 4 & 4 & 1 & $\geqslant 6$ & $\geqslant 6$ & $\geqslant 6$ & 4 \\
\hline Caecum & $\geqslant 6^{*}$ & $\geqslant 6^{*}$ & $\geqslant 6^{*}$ & $\geqslant 6^{*}$ & $\geqslant 6^{*}$ & $\geqslant 6^{*}$ & $4^{*}$ & $\geqslant 6^{*}$ & $\geqslant 6$ & $\geqslant 6$ & $\geqslant 6$ & 4 & $\geqslant 6$ & 4 & 4 & 2 \\
\hline Spiral colon & $\geqslant 6$ & $\geqslant 6$ & $\geqslant 6$ & $\geqslant 6$ & $\geqslant 6$ & $\geqslant 6$ & 1 & $\geqslant 6$ & $\geqslant 6$ & $\geqslant 6$ & $\geqslant 6$ & 4 & $\geqslant 6$ & $\geqslant 6$ & 4 & - \\
\hline Terminal colon tissue & 4 & 4 & 2 & 4 & $\geqslant 6$ & $\geqslant 6$ & - & $\geqslant 6$ & $\geqslant 6$ & 2 & - & 2 & $\geqslant 6^{*}$ & $\geqslant 6^{*}$ & $4^{*}$ & $2^{*}$ \\
\hline Terminal colon content & - & 2 & - & - & $\geqslant 6$ & $\geqslant 6$ & - & $\geqslant 6$ & $\geqslant 6$ & $\geqslant 6$ & - & 4 & $\geqslant 6$ & $\geqslant 6$ & $\geqslant 6$ & 4 \\
\hline Rectum tissue & 4 & 4 & - & 4 & - & - & - & - & $\geqslant 6$ & 2 & - & 2 & $\geqslant 6^{*}$ & $4^{*}$ & $2 *$ & $-*$ \\
\hline Rectum content & 2 & 2 & - & 2 & - & - & - & - & $\geqslant 6$ & $\geqslant 6$ & - & $\geqslant 6$ & $\geqslant 6$ & $\geqslant 6$ & $\geqslant 6$ & 2 \\
\hline
\end{tabular}

See footnote to Table 1 .

${ }^{*}$ Sites where attaching-effacing lesions were detected histologically. ${ }^{\dagger}$ In the absence of histological changes, the low numbers of E. coli O157 may represent contamination rather than invasion. 
Both terminal colon and rectum were well colonised by E. coli $\mathrm{O} 157$ in lambs $\mathrm{C}$ and $\mathrm{D}$, at 60 and $84 \mathrm{hpi}$, respectively. The ileum of all animals yielded modest numbers of $E$. coli $\mathrm{O} 157$, and low numbers were recovered from the rumen. Low numbers of organisms were recovered from the mesenteric lymph nodes of one animal and the tonsils of three.

\section{Pathological findings}

Light microscopy. In the small intestine, mild to focally moderate infiltration of the lamina propria by eosinophils or neutrophils, or both, was present in the ileum of lamb $\mathrm{C}$, the jejunum and ileum of lambs B and $\mathrm{D}$, and the duodenum and ileum of lamb $\mathrm{A}$. Neutrophils were transmigrating across the mucosal epithelium in some sections.

In the large intestine, sections of bowel wall were taken from tissue samples measuring 75-200 $\mathrm{mm}$ in length from each sampling site. A total of 197 large intestine H\&E sections were studied in detail and only seven AE-type lesions were seen. AE lesions were seen at the mucosal surface in the caecum of lamb A sampled at $12 \mathrm{hpi}$, the caecum of lamb B sampled at 36 hpi and in the terminal colon and rectum of lamb D, sampled at 84 hpi. No lesions were seen in the tissues of lamb C. Each lesion extended over 3-15 adjacent enterocytes which usually protruded slightly, either singly or as a group, above the surrounding mucosal surface (Fig. 1). Affected enterocytes often appeared to have rounded up, and some showed condensation of nuclear material. One caecal lesion was accompanied by an overlying clump of neutrophils, some of which appeared to contain bacteria. Detachment of a colonised enterocyte from the mucosa was also observed.

Mild to focally moderate infiltration of the lamina propria by eosinophils and neutrophils was present throughout the large intestine in all animals. There was no evident association between infiltration and the presence of visible AE lesions. Occasionally, transmigration of neutrophils across the intestinal epithelium was seen. Pathological changes were not seen in sections of rumen, liver, kidney, tonsil, mesenteric lymph node and spleen from any animal.

For immunohistochemistry, three pieces of embedded tissue comprising caecum from lamb A (12 hpi), and terminal colon and rectum from lamb D (84 hpi), were selected based upon the identification of five $\mathrm{AE}$ lesions in H\&E sections prepared from these tissues. Another two pieces of terminal colon and one piece of rectum from lamb D were also selected. Sections cut from embedded tissue adjacent to those used for H\&E examination were immunostained, but none of the five lesions that had previously been identified was detected. However, one further lesion was found in an immunostained section of rectum from lamb $\mathrm{D}$. The adherent bacteria were positively and specifically labelled by the $\mathrm{O} 157$ antiserum (Fig. 2). In a section of caecum from lamb $\mathrm{A}$, intestinal contents were seen to contain a large number of specifically labelled O157 organisms.

Electron microscopy. Of the two focal lesions processed for electron microscopy, only the lesion in the rectum of lamb D ( $84 \mathrm{hpi}$ ) was seen in thin sections. Typical AE lesions, with intimate attachment to the enterocyte plasma membrane, formation of pedestals and effacement of the host cell microvilli were observed (Fig. 3). A few bacteria which were dividing whilst attached to the mucosal surface were evident. The immunogold technique with the O157 antiserum specifically labelled the cell wall of adherent bacteria in the lesion (Fig. 4).

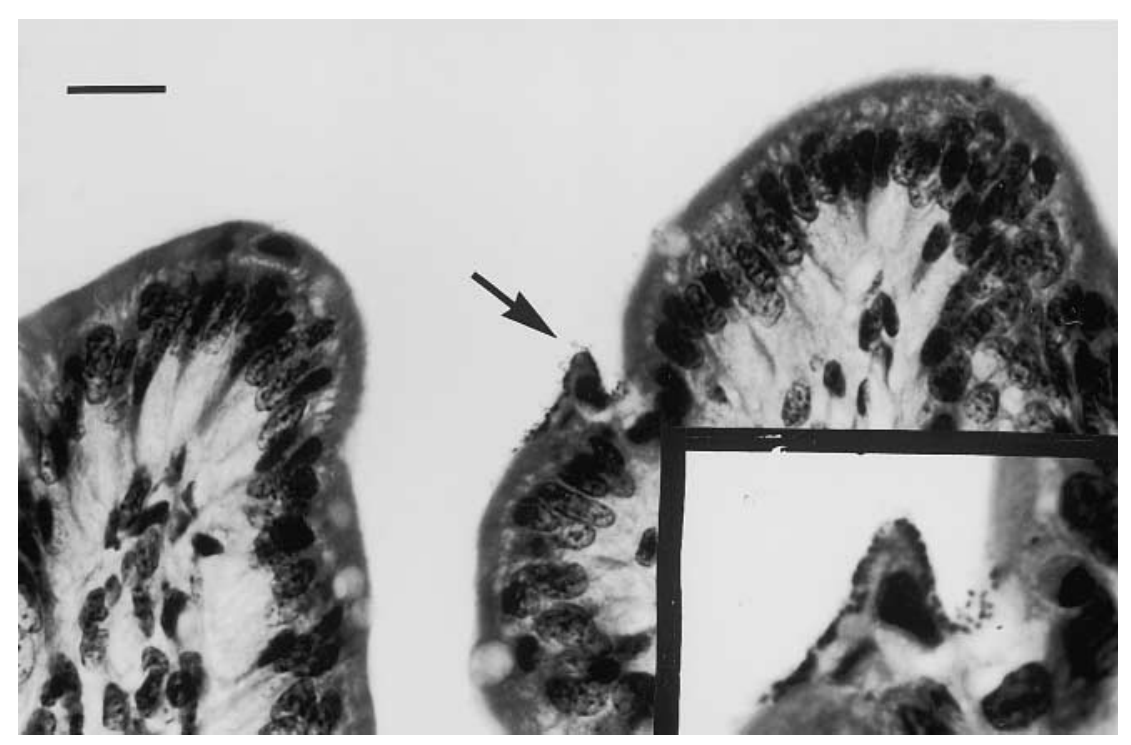

Fig. 1. Rectum, 84 hpi. Attaching-effacing lesion (arrow). Affected enterocytes protrude from the mucosal surface. Closely adherent bacteria are evident at higher magnification (inset). Haematoxylin and eosin, bar $=30 \mu \mathrm{m}$. 


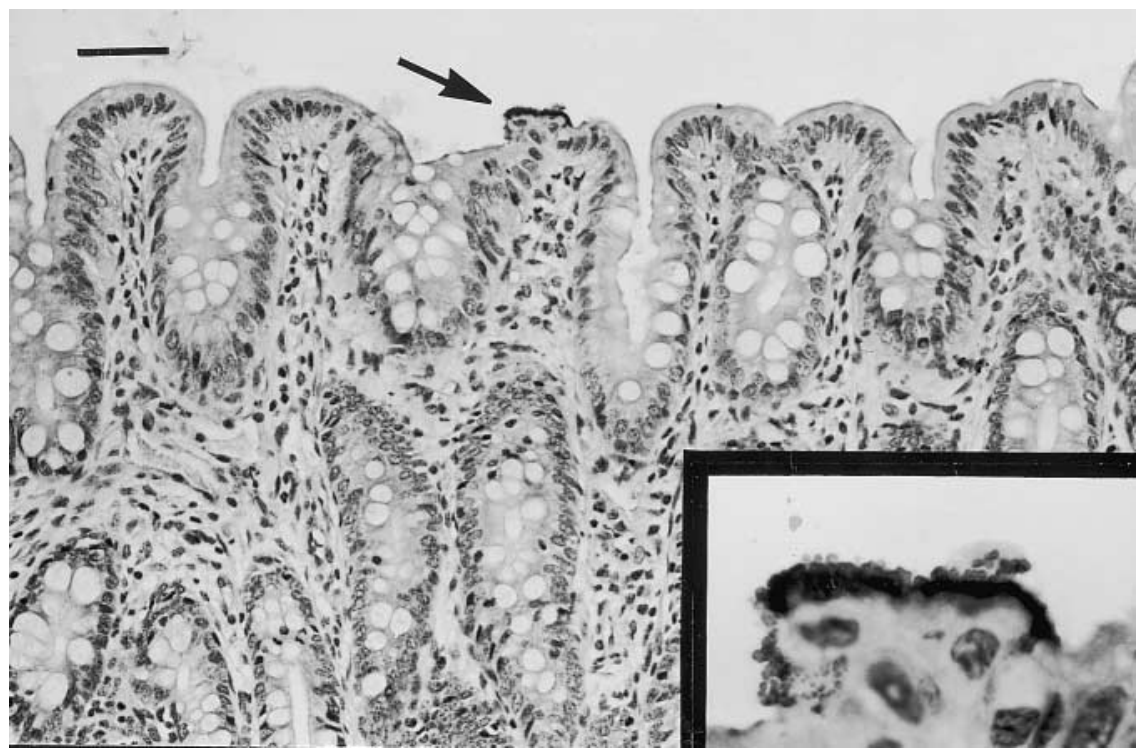

Fig. 2. Rectum, 84 hpi. Attaching-effacing lesion (arrow) protrudes from the mucosal surface. Specifically labelled $E$. coli are evident at higher magnification (inset). Anti-O157 immunoperoxidase, bar $=60 \mu \mathrm{m}$.

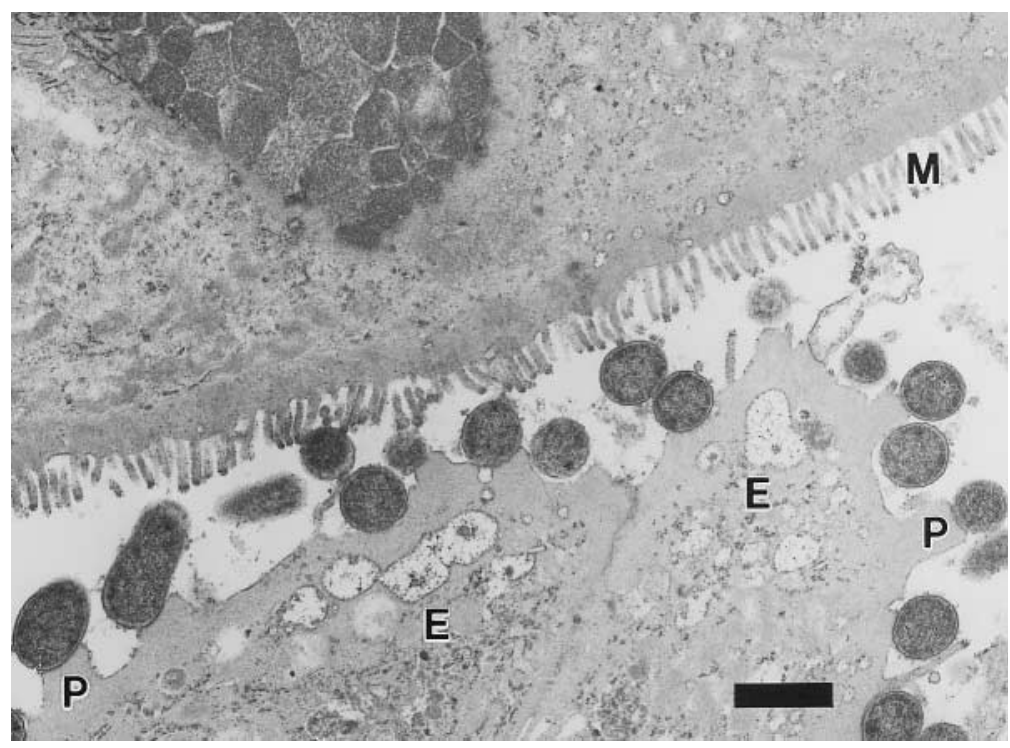

Fig. 3. Rectum, 84 hpi (same lesion as Fig. 1). Bacteria adhere intimately to the enterocyte (E) surface. Microvilli are effaced and some bacteria are on pedestals (P). A normal microvillous border (M) is present on uncolonised adjacent enterocytes. Bar $=1 \mu \mathrm{m}$.

\section{Discussion}

This is the first report that has clearly demonstrated that E. coli $\mathrm{O} 157: \mathrm{H} 7$ induced $\mathrm{AE}$ intestinal lesions in colonised sheep. The lesions in these lambs were not associated with clinical disease. Detailed histological examination revealed small, sparse $\mathrm{AE}$ lesions in the large intestine in animals necropsied at 12, 36 and $84 \mathrm{hpi}$. The restriction of lesions to the large intestine is consistent with the $\gamma$-intimin subtype of EHEC O157:H7 [9]. Despite the evidence of high numbers of E. coli $\mathrm{O} 157: \mathrm{H} 7$ in the intestinal lumen, very few $\mathrm{AE}$ lesions were observed. Routine immunostaining failed to demonstrate those $\mathrm{AE}$ lesions that had been seen in the H\&E sections, most probably because they spanned relatively few sequential $4-\mu \mathrm{m}$ paraffin wax sections. In this situation, use of both light and electron microscopic immunological techniques optimised the chance of successful antigen detection.

The prevalence of E. coli $\mathrm{O} 157: \mathrm{H} 7$ in sheep is lower than in cattle $[5,6]$ and a reduced capacity to colonise may contribute to this. Whilst the observed frequency and size of $\mathrm{AE}$ lesions in this study is, of necessity, based upon examination of a small proportion of the mucosal surface, it is possible that intimate association between $\mathrm{O} 157: \mathrm{H} 7$ organisms and the ovine intestinal mucosa is in some way less effective than in cattle. In neonatal $\mathrm{CD}$ calves inoculated with a single strain of EHEC 0157:H7 at $<12 \mathrm{~h}$ of age, extensive AE lesions were observed, and fewer lesions were reported from similarly inoculated CF calves [12]. Therefore, the 


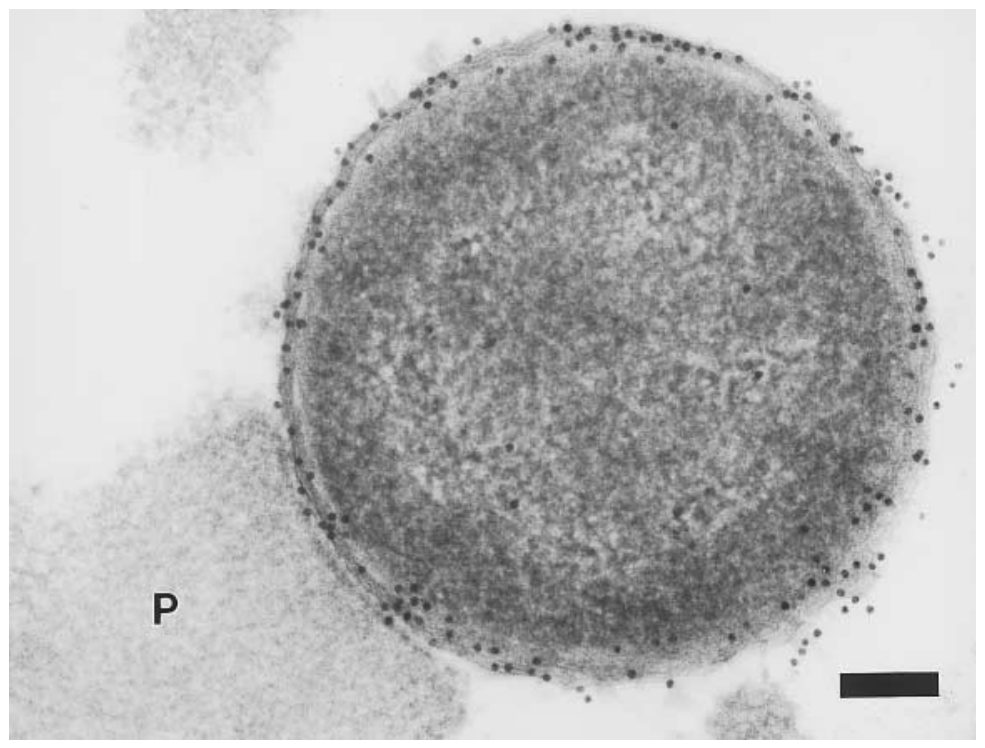

Fig. 4. Rectum, 84 hpi (same lesion as Fig. 1). Bacterium intimately attached to a pedestal (P). Gold particles are localised to the bacterial cell membrane. Anti-O157 immunogold label, bar $=100 \mathrm{~nm}$.

relative paucity of lesions detected in the present study may partly reflect the protective effect of colostrum. However, even in the $\mathrm{CF}$ neonatal calves AE lesions covering between $10 \%$ and $50 \%$ of the caecal mucosal surface were reported [12], which is considerably more extensive than in the present study. This difference between the calf and lamb studies may be due to differences between any or all of several factors - host species, host age, dose sizes and inoculum strains. Whether inoculation of younger lambs or more prolonged exposure would lead to establishment of more or larger lesions, or both, is unknown. The lesions reported in neonatal calves followed an inoculum of $10^{10}$ EHEC O157:H7 organisms, in contrast to the $10^{9}$ organisms used in the present study. A correlation between the concentration of organisms in the tissue and the detection of $\mathrm{AE}$ lesions in weaned calves inoculated with a single strain has been reported [15]. The abilities of the non-ovine-derived EHEC O157:H7 strains used in this work to colonise the ovine mucosa, when compared with other experimental strains and ovine field strains, are unknown. Finally, a possible effect of inter-strain competition on the formation of AE lesions in the present study cannot be discounted.

The recovery of the four strains from faeces and tissues was not uniform. The $\operatorname{str}^{r}$ and the nal $^{r} / \mathrm{rif}^{r}$ strains were recovered in lower numbers than either the nal or the rif $^{r}$ strains. Strain differences related to colonisation of the ovine host, or attenuation due to the antibiotic resistance marking may have contributed to the differences in recovery of bacteria.

It is established that sheep are reservoirs for $E$. coli O157:H7 [5-8], but this is the first report that has demonstrated AE lesions in colonised sheep. There is some evidence to suggest that sheep may become persistently colonised $[20,21]$. The findings in this study indicate that the well-characterised mechanisms for intimate attachment encoded by the LEE of EHEC O157:H7 may contribute to the initial events, at least, of colonisation. Whether these initial events are significant in persistent colonisation remains to be determined.

We gratefully acknowledge the support given by the Animal Services Unit, VLA (Weybridge) for the provision of animals, Roberto La Ragione and Mike Dibb-Fuller for logistical support, and $\mathrm{Mr} \mathrm{J}$. Conibear for photographic prints. This work was supported by the Ministry of Agriculture, Fisheries and Food, UK, through the Food Safety and Zoonoses programme, project OZ0706 and by the VLA seedcorn funding programme, project SC0081.

\section{References}

1. Smith HR, Scotland SM. Isolation and identification methods for Escherichia coli $\mathrm{O} 157$ and other vero cytotoxin producing strains. J Clin Pathol 1993; 46: 10-17.

2. Boyce TG, Swerdlow DL, Griffin PM. Escherichia coli O157:H7 and the hemolytic-uremic syndrome. N Engl J Med 1995; 333: 364-368.

3. Swinbanks D. Japan shuns radishes after "possible link" to $E$. coli. Nature 1996; 382: 567.

4 Griffin PM, Tauxe RV. The epidemiology of infections caused by Escherichia coli $\mathrm{O} 157$, other enterohaemorrhagic E. coli, and the associated hemolytic uremic syndrome. Epidemiol Rev 1991; 13: 60-98.

5. Chapman PA, Siddons CA, Cerdan Malo AT, Harkin MA. A 1-year study of Escherichia coli 0157 in cattle, sheep, pigs and poultry. Epidemiol Infect 1997; 119: 245-250.

6. Heuvelink AE, van den Biggelaar FL, De Boer E et al. Isolation and characterization of verocytotoxin-producing Escherichia coli O157 strains from Dutch cattle and sheep. $J$ Clin Microbiol 1998; 36: 878-882.

7. Meng J, Zhao S, Doyle MP. Virulence genes of Shiga toxinproducing Escherichia coli isolated from food, animals and humans. Int J Food Microbiol 1998; 45: 229-235.

8. Fegan N, Desmarchielier P. Shiga toxin-producing Escherichia coli in sheep and pre-slaughter lambs in eastern Australia. Lett Appl Microbiol 1999; 28: 335-339.

9. Nataro JP, Kaper JB. Diarrheagenic Escherichia coli. Clin 
Microbiol Rev 1998; 11: 142-201.

10. Donnenberg MS, Tzipori S, McKee ML, O'Brien AD, Alroy J, Kaper JB. The role of the eae gene of enterohemorrhagic Escherichia coli in intimate attachment in vitro and in a porcine model. J Clin Invest 1993; 92: 1418-1424.

11. Tzipori S, Gunzer F, Donnenberg MS, de Montigny L, Kaper $\mathrm{JB}$, Donohue-Rolfe A. The role of the eaeA gene in diarrhea and neurological complications in a gnotobiotic piglet model of enterohemorrhagic Escherichia coli infection. Infect Immun 1995; 63: 3621-3627.

12. Dean-Nystrom EA, Bosworth BT, Cray WC, Moon HW Pathogenicity of Escherichia coli $\mathrm{O} 157: \mathrm{H7}$ in the intestines of neonatal calves. Infect Immun 1997; 65: 1842-1848.

13. Dean-Nystrom EA, Bosworth BT, Moon HW, O'Brien AD Escherichia coli $\mathrm{O} 157: \mathrm{H} 7$ requires intimin for enteropathogenicity in calves. Infect Immun 1998; 66: 4560-4563.

14. Woodward MJ, Gavier-Widen D, McLaren IM, Wray C, Sozmen M, Pearson GR. Infection of gnotobiotic calves with Escherichia coli O157:H7 strain A84. Vet Rec 1999; 144: 466-470.

15. Dean-Nystrom EA, Bosworth BT, O'Brien AD, Moon HW Bovine infection with Escherichia coli O157:H7. In: Stewart CS, Flint HJ (eds) E. coli $\mathrm{O} 157$ in farm animals. Wallingford, CAB International. 1999: 51-58.

16. Cray WC, Moon HW. Experimental infection of calves and adult cattle with Escherichia coli O157:H7. Appl Environ Microbiol 1995; 61: 1586-1590.
17. Brown CA, Harmon BG, Zhao T, Doyle MP. Experimental Escherichia coli $\mathrm{O} 157: \mathrm{H} 7$ carriage in calves. Appl Environ Microbiol 1997; 63: 27-32.

18. Wray C, McLaren IM, Randall LP, Pearson GR. Natural and experimental infection of normal cattle with Escherichia coli O157. Vet Rec 2000; 147: 65-68.

19. Mechie SC, Chapman PA, Siddons CA. A fifteen month study of Escherichia coli $\mathrm{O} 157: \mathrm{H} 7$ in a dairy herd. Epidemiol Infect 1997; 118: 17-25.

20. Cornick NA, Booher SL, Casey TA, Moon HW. Are ruminants a biological or accidental reservoir for VTEC O157? In: Duffy G, Garvey P, Coia J, Wasteson Y, McDowell DA (eds) Pathogenicity and virulence of verocytotoxic E. coli. Dublin, Teagasc. 1999: 43-50.

21. Kudva IT, Hunt CW, Williams CJ, Nance UM, Hovde CJ. Evaluation of dietary influences on Escherichia coli O157:H7 shedding by sheep. Appl Environ Microbiol 1997; 63: $3878-3886$.

22. Wales AD, Clifton-Hadley FA, Cookson AL, Dibb-Fuller MP, La Ragione RM, Sprigings KA, Pearson GR, Woodward MJ. Experimental infection of six-month old sheep with Escherichia coli 0157:H7. Vet Rec 2001; 148: 630-631.

23. Knutton $\mathrm{S}$, Baldwin $\mathrm{T}$, Williams $\mathrm{PH}$, McNeish AS. Actin accumulation at sites of bacterial adhesion to tissue culture cells: basis of a new diagnostic test for enteropathogenic and enterohemorrhagic Escherichia coli. Infect Immun 1989; 57: $1290-1298$. 